\title{
The Model of Teachers Communication Based on Multicultural Values in Rural Early Childhood Education
}

\author{
Dakir $^{\circledR}{ }^{\bowtie}$, Akmal Mundiri², Muhammad Ainul Yaqin $^{2}$, Niwati $^{3}$, Ida Subaida $^{3}$ \\ Manajemen Pendidikan Islam, Institut Agama Islam Negeri Palangkaraya, Indonesia(1) \\ Manajemen Pendidikan Islam, Universitas Nurul Jadid, Paiton, Probolinggo, Indonesia(2) \\ Pendidikan Islam Anak Usia Dini, Universitas Nurul Jadid, Paiton, Probolinggo, Indonesia(3) \\ DOI: $\underline{10.31004 / o b s e s i . v 6 i 4.2125}$
}

\begin{abstract}
The phenomenon of the absence of moral decadence and appropriate behavior such as violence, brawls, exclusivism, and a lack of tolerance and respect for others in all forms involving students is an ineffective model of education and function. The dysfunction is caused by not conveying the message desired by the teacher. Thus, this study aimed to describe the multicultural values-based teacher communication model in early childhood education institutions in rural areas. This research used a case study approach. This study indicates that the multicultural value-based teacher communication model in early childhood education institutions in rural areas is carried out in the form of verbal and non-verbal communication. In verbal communication, messages are conveyed verbally and in writing. Meanwhile, in the non-verbal communication process, the messages conveyed are in the form of persuasive power, coercive and reward power, personal imitation, and educative interactions vertically and horizontally.
\end{abstract}

Keywords: communication models; multicultural values; teacher

\begin{abstract}
Abstrak
Fenomena tidak adanya dekadensi moral dan perilaku pantas seperti kekerasan, tawuran, eksklusivisme, serta kurangnya toleransi dan penghargaan terhadap orang lain dalam segala bentuk bentuk yang melibatkan peserta didik merupakan bentuk tidak efektifnya model pendidikan dan fungsi. Disfungsi tersebut diakibatkan oleh tidak tersampaikannya pesan yang diinginkan oleh guru. Dengan demikian, penelitian ini bertujuan untuk memahami model komunikasi guru berbasis nilai multikultural di lembaga pendidikan anak usia dini di pedesaan. Penelitian ini menggunakan pendekatan pendekatan dengan jenis studi kasus. Adapun hasil dari penelitian ini menunjukkan bahwa model komunikasi guru berbasis nilai multikultural di lembaga pendidikan anak usia dini di pedesaan dilakukan dalam bentuk komunikasi verbal dan non verbal. Dalam proses komunikasi verbal, pesan yang disampaikan melalui lisan dan tulisan. Sedangkan dalam proses komunikasi non verbal, pesan yang disampaikan dalam bentuk persuasive power, coersive dan reward power, personal imitation, dan interaksi edukatif secara vertikal dan horizontal.
\end{abstract}

Kata Kunci: model komunikasi; nilai multikultural; guru

Copyright (c) 2022 Dakir, et al.

$\triangle$ Corresponding author:

Email Address : dakir@iain-palangkaraya.ac.id (Palangkaraya, Indonesia)

Received 22 November 2021, Accepted 23 January 2022, Published 27 February 2022 


\section{INTRODUCTION}

Learning in early childhood has been an essential discussion until now (Zamroni, Amir, et al., 2021). The current learning context deals with situations that allow students to experience boredom due to unpleasant learning (Amaliyah et al., 2022). Early Childhood Education is a vehicle for playing while learning, full of fun and freedom (Iltiqoiyah, 2020; Mundiri \& Hamimah, 2022). Thus enabling children to express and develop their talents, interests, and creativity. At the same time, gaining knowledge of skills and developing children's behavior in a pleasant atmosphere (Umiarso \& Hidayati, 2022). Learning is a business process carried out by a person to obtain a new change due to his own experience in interaction with his environment. The expected form of relationships and interactions is a pleasant, familiar, understanding, and wanting to understand atmosphere so that students feel that they have been educated with love and responsibility. This form of social-educational relations and interactions that are intimate and full of kinship between teachers and students is very beneficial because it will become a model in students' daily interactions with their friends and their environment (Zamroni, Bali, et al., 2021). The expected form of relationship and interaction is the existence of a pleasant, intimate, understanding, and wanting to understand atmosphere so that students feel that they have been educated with love and responsibility. This friendly and familial form of social-educational relations and interactions between teachers and students is very beneficial because it will become a model in students' daily interactions with their friends and their environment (Intania, 2020). In learning, of course, there is a communication process and interaction between individuals in it. Individual A interacts with individual B and forms a fiduciary field (C). According to Soekanto said, "The social process of content in this fiduciary field is the process of imitation, suggestion, identification, sympathy (Soekanto, 1990). These loads can run independently or simultaneously. Provided that two conditions must be met, namely continuous social contact and continuous communication. Teaching and learning activities between teachers and students are a form of continuous social contact (Baharun, 2015; Fachri et al., 2020). This social contact will continue to be built if the communication they develop will also continuously occur. Social contacts only built during curricular activities are not enough to form a meaningful fiduciary field in education (Mundiri \& Adhimiy, 2019),

The description above emphasizes the urgency of the teacher's role in the learning process (al-mudarris ahammu min al-maddah). Teachers have an important position in managing active learning (Bali et al., 2020; Farisi \& Wafi, 2021). Active learning has the meaning of increasing teacher competence. The teacher is responsible for the policy line inherent in the teacher because the teacher has a variety of names according to the study of Islamic education thought. The teachers' names include ustadz, mu'allim, murabbiy, mursyid, mudarris, and muaddib, which means people who provide knowledge intending to educate foster the morals of students to become people with good personalities. (Muhaimin, 2005). This goal is not directly proportional to the current environment of students dealing with the global era, with territorial boundaries that do not hinder cultural transformation. The developing culture strongly influences the personality of students (Sholeha \& Anggraini, 2022).

Meanwhile, the cultural heritage built in schools tends to be homogeneous, making it very vulnerable to cultures that do not follow the plurality of ethnic cultures and eastern traditions (Rizqiyah, 2020). These global living conditions, directly or indirectly, affect the life values of teachers. Education as a social system is required to anticipate changes in the value order that occur in society. The educational curriculum should reflect the values of independence as the core value of education and the value of excellence as the most excellent value. Both values must be through education that develops proper understanding, courage to think, courage to act, firmness of opinion, all of which are based on the teachers' beliefs.

Likewise, education with a multicultural perspective will also be formed from school learning patterns, family, or the environment. In multicultural education in schools, the role 
of the teacher occupies a fairly urgent position. The task of educators has a very noble responsibility if it can be carried out well in educational institutions. The professionalism of educators is essential to encourage the implementation of teacher duties that deal with the concepts of values and systems of human civilization.(Kinoshita, 2007) However, teachers can read factual cases in society. He is to bridge between concepts and reality so that it has a functional impact and benefits what has been learned. This can commonly be called a competency that provides space for the development of the professional expertise of the teacher. The basic competence of teachers is based on the stages of sensitivity to the weight of the primary potential and tendencies it has. Competence requires the preparation of teachers to master the knowledge, skills, and special abilities related to the profession in the field of teaching subjects. Competence builds skills in teaching and learning in the classroom. Teachers are encouraged to improve their abilities to meet the requirements of professional teachers. Teachers must possess competencies based on Law Number 14 of 2005 concerning Teachers and Lecturers in Chapter IV, which emphasizes four competencies: pedagogic, professional, personality, and social competencies (Saud, 2009). Children at an early age are a sensitive period to receive influences from their environment (Rozi \& Maulidiya, 2022; Wahid et al., 2022). This is an opportunity for the environment, in this case, the parents-teacher-school, to provide the broadest possible educational influence on the child to help develop positive child behavior. One approach to educating faith and piety is religious education from an early age.

The learning process carried out in schools is a transformation process that takes quite a long time. The learning process carried out is expected to impact the ability of students in terms of awareness and good prejudice against other parties. This is, of course, in line with students' level of development. In delivering lecture and training materials to students, several factors must be considered, including students, classrooms, methods, and the material itself. Learning and communication methods must receive serious attention in every process to achieve the goals. Learning and communication methods do not always have to be the same for every material. On the other hand, pluralism awareness must be able to build a robust system to impact the ability of professional teachers. The position of teacher professionalism is one of the competencies that must be articulated by multiculturalism (Wahid et al., 2020). This aspect requires teachers to build an inclusive self-image, tolerance, and equality in learning and practice in the school community. Schools planned to build values, concepts, and practices sourced from universal values. The cultural diversity of school residents has given birth to a wealth of cultural diversity if teachers cannot manage harmful actions between school members. This idea was born out of the fact that differences between people have ethnic origins and the birth of history. Different life experiences raise awareness and different values, which sometimes appear contradictory. Human encounters with different ethnic backgrounds are increasingly spreading across national and state territorial boundaries to continental boundaries, raising awareness of otherness that is carried by every ethnicity and nation in the world. Some of these differences are skin color, body posture, language, traditions, outlook on life, adherents, and religious understanding.(Mulkhan, 2005)

Multiculturalism is relevant to Bhineka Tunggal Ika, which has unique characteristics and the ideal of multiculturalism in Indonesia. This plurality characteristic has given birth to Indonesia, with several population educational backgrounds that are still low.(Mundiri \& Tohet, 2018) These conditions affect the dynamics of the nation and society, especially the teachers tasked with preparing the nation's generation who play a role as pioneers in building multicultural awareness. Schools are effective places for teachers to build learning media that reflect diverse cultural treasures. The teacher has a direct position to facilitate students' basic needs as one of the social beings who need social actualization in the stage of forming an inclusive and wise personality at the level of formal education (Ratcliff et al., 2010; Adham \& Mahmudah, 2021)

Research on teacher communication models was also conducted by Windayati et al., which focused on teacher communication in language learning. The study results found that 
the teacher's communication strategies were literal translation, code-switching, non-linguistic learning, message abandonment, circumlocution, self-improvement, approximation, understanding checks, interpretive summaries, and responses (Windayanti et al., 2017). In addition, many other studies that discuss teacher-student interactions have also been carried out by researchers in China and America. Communication between students and teachers in America is created to control student behavior so that students can control more than is caused by the Stricter Teacher.(Jiang et al., 2021) Based on this description, the focus of the research conducted discusses communication and teacher interactions with teachers. Thus, no research focuses on teacher communication models in multicultural-minded education, especially in early childhood education institutions in rural areas.

\section{METHODOLOGY}

This study aims to understand The Model of Teachers' Communication Based on Multicultural Values in Rural Early Childhood School. Thus this research was conducted using a qualitative approach with the type of case study. This approach is directed at the background of the individual holistically. At the same time, the case study aims to find out about the case of the Model of Teachers Communication Based on Multicultural Values in Rural Early Childhood School in depth. This research was conducted at the Rural Early Childhood School, Krucil Probolinggo. Rural communities have the uniqueness that distinguishes them from urban communities. Rural communities tend to be more receptive to differences while maintaining locality and local traditions. Likewise, the educational process in early childhood education institutions is unique from educational institutions in urban areas, both in terms of learning management and infrastructure. The data in this study were obtained through participant observation techniques, in-depth interviews, and documentation. The data collected was analyzed using the Miles and Huberman data analysis technique, which consists of data reduction, data display, and verification. To obtain credible data, the researcher used a technique to check the validity of the data, which consisted of an extension of participation, persistence of observation, and triangulation. Research design presented on figure 1.

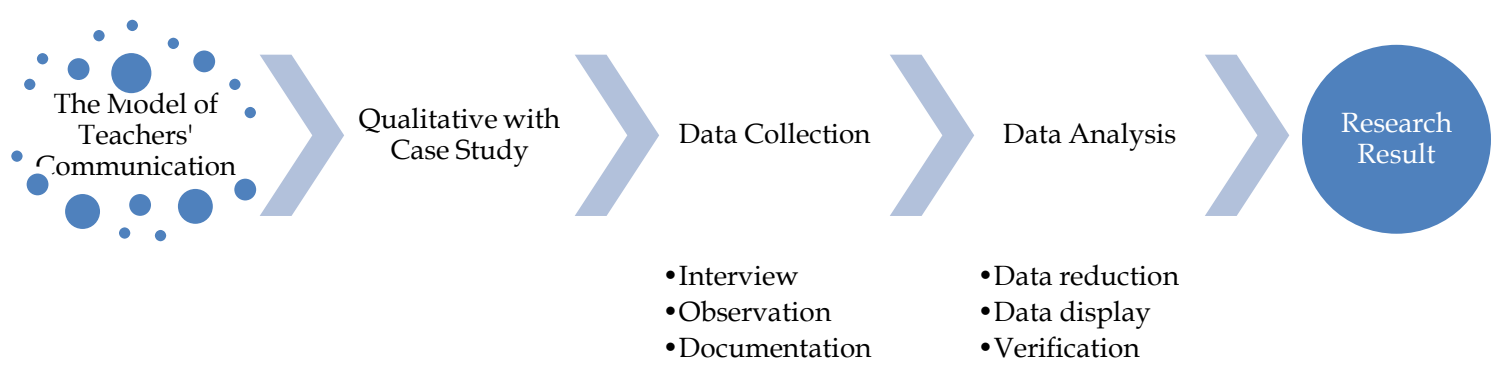

Figure 1: Research Design

\section{RESULTS AND DISCUSSION}

Human resources in the context of management are "people who are ready, willing, and able to contribute to organizational goals." Therefore, Human Resources in an organization, including educational organizations, require good management and development to improve their performance to contribute to achieving goals. The increased performance of Human Resources will impact the better performance of the organization in carrying out its role in society. There is an educative interaction between students and teachers in the educational process. The effect of effective, educative education between teachers and students will cause an imitation effect, whether intentional or not because teachers in any educational institution have sufficient influence. Great, admired, and has many advantages.

Teaching is a profession. That is, the person with the title is a professional. The implication is that no one who is not an expert in teaching has the right to hold the title of 
teacher. Because of that professionalism, everyone called a teacher must have unique abilities and expertise (Page \& Jones, 2018). Thus, the position of a teacher should be given to those who are ready and interested, not to those who need work because they cannot compete in other fields (Sudjana, 1988). As professionals, teachers must have skills (based on in-depth concepts and knowledge), expertise, professional education, sensitivity to effects, and readiness to develop. Teachers are also required to understand the teacher's code of ethics and pay attention to students.

The phenomenon of increasing moral decadence and disgraceful behavior such as violence, brawls, exclusivism, and weak tolerance and respect for others in all its forms involving school children is an accurate indicator of the ineffectiveness of basic education models and functions that have been carried out due to not getting the desired message. The results of this study indicate that the model and meaning of teacher communication in multicultural-minded learning in early childhood education in rural areas is carried out in the form of;

\section{Verbal Communication Based on Moral Reasoning}

Every living thing in this world must communicate, whether it is through sounds, vibrations, or movements that have meaning in a particular community of life. As creatures who have a noble predicate compared to other creatures, humans certainly carry out communication activities. This is, of course, reasonable, considering that every human being cannot live alone and needs to grow and develop with other humans, both for the sake of his survival, the safety of his life, and for the sake of his descendants.

The two primary forms of communication are verbal communication and nonverbal communication. Verbal communication is a form of communication in which messages are delivered both in writing and orally. At the same time, nonverbal communication is done using body movements, facial expressions, symbols, and voice intonation. In the communication process, the two forms of communication occur together, where nonverbal communication complements or complements verbal language.

Based on the study results, it was found that the teacher's communication model with multicultural insight was carried out with a verbal communication model. The form of verbal communication carried out in learning is a learning method that emphasizes the indoctrination of Islamic teachings, which are tawassuth, tawazun, tasamuh, and 'is. The practice of verbal communication by teachers in the context of internalizing multicultural values is carried out either in oral or written communication. In oral communication, the teacher gives the doctrine of the beauty of sharing by exemplifying and demonstrating the negative impact of togetherness in a frame of difference. In the oral communication process with indoctrination techniques, there are stages to carry out the procedure, namely a) the brainwashing stage. The teacher starts cultivating values by destroying or disrupting the established value systems in students so that they do not have a stand. Teachers can use methods to confuse students' minds by asking and answering questions. And in-depth interviews with analytic techniques, and so on. When his mind is empty, and his rational consciousness is no longer able to control himself, and his stance is lost, then proceed to the next stage; b) the stage of establishing fanaticism, namely the teacher is obliged to instill new ideas that are considered correct so that the values that are instilled can enter the child's head without going through well-established rational considerations. In instilling this fanaticism, a dynamic approach is used more than a rational approach. When students are willing to accept these values emotionally, then the doctrine is implanted; c) the stage of doctrinal cultivation. At this stage, the teacher can use a dynamic approach; exemplary. In this case, the planting of this doctrine is only known as one truth value presented, and there is no other alternative. In this case, all students must accept the truth without questioning the nature of the truth.

In addition, in the oral communication technique, the teacher can do the technique of moral reasoning. In this case, this technique is carried out through several stages: a) presenting 
a moral dilemma. At this stage, students are faced with problematic values that are contradictory, from simple to complex ones. The method of presentation can be through observation, reading newspapers/magazines, listening to plays, watching movies; $b$ ) after presenting the problematic moral dilemma, it can be continued with the division of discussion groups. Students are divided into small groups to discuss some observations on the moral dilemma; c) bring the results of group discussions into class discussions, to clarify values, making alternatives and their consequences; d) after students discuss intensively and select the selected values according to the proposed alternatives, then students can organize the selected values into themselves. To find out whether students have organized these values into themselves, it can be known through students' opinions, for example, through essays compiled after the discussion or follow-up actions from the discussion activities. In writing communication techniques, research findings show that teachers to learn multicultural values internalize by writing about harmony and differences in almost every school corner.

\section{Non-verbal Communication}

In non-verbal communication carried out in the context of internalizing multicultural values, attitudes, perceptions, beliefs, and behavior of school staff also affect school performance in terms of internalizing multicultural insights. All staff who support learning will greatly help create the desired learning conditions and vice versa. If school staff is used to speaking with good manners and politeness, students will also be accustomed to using it at school and home, and in the community. This means that school staff needs to be selected and appointed from people who understand and are equipped with the appropriate education. School staff does not just deal with inanimate objects such as paper, rulers, stationery, or plants but interacts with all school components. The cynical and uncaring attitude of school staff will significantly affect school performance. For that, it is necessary to choose suitable people for the profession.

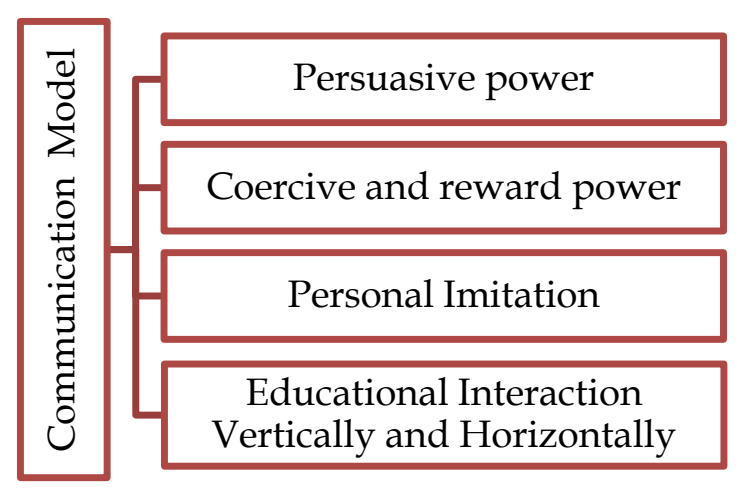

Figure 2: the communication model and teacher-student interaction

Multicultural education must be seen as an ongoing process, not something we "do immediately." Therefore solving this problem becomes the target of multicultural education reform. Let us ask school staff who are trying to implement Multicultural Education in their schools. They said that their schools have "done" Multicultural Education last year and are now starting other reforms, such as improving reading scores. This administrator does not understand the nature and scope of Multicultural Education and does not understand that the primary goal of Multicultural Education is to improve academic achievement. Therefore, in order to build multicultural insight in students, the communication model and teacher-student interaction can be done with non-verbal communication, which can be done by figure 2 .

\section{Persuasive power}


Non-verbal communication models in the internalization of multicultural values are carried out using persuasive power. In compelling force, the teacher uses (utilizes) psychological and sociological data and facts from the communicant. Thus, persuasion is not an act of persuading a person or a group to accept an opinion and do it, but a technique to influence humans by using (utilizing) psychological and sociological data and facts from the communicant. Persuasion is not an act of persuading a person or a group to accept an opinion and do it, but a technique to influence humans by using (utilizing) psychological and sociological data and facts from the communicant.

In the context of learning, as in this study, the persuasive power exercised by teachers in the context of multicultural-minded education is done by influencing students with a psychological approach so that students follow the teacher's invitation but feel like doing something of their own free will (Mubarak, 1999). Persuasive da'wah can also be defined as an activity to spread Islamic teachings by using psychological data and facts from students to find the truth and awareness that makes their attitudes and behavior influenced and directed to accept and implement Islamic teachings (Slamet, 2009).

Thus persuasive da'wah emphasizes that the activities carried out by the teacher are in the form of convincing and awakening students to accept and implement multicultural messages, not forcing students to carry out multicultural messages. The persuasive method is the delivery of information and multicultural insights through the communication process, in which there is a process of motivating and persuading students to receive multicultural messages. The da'wah carried out is expected to direct and shape certain behaviors. Therefore, compellingly, the message conveyed contains an effort to encourage and influence students so that their opinions, attitudes, and behavior are multicultural with their awareness and without coercion.

Communication can be successful if communication can change a person's attitudes and actions. One way is by using persuasive communication (Susanto, 1992). Effendy suggests that "persuasive communication is a communication that is carried out in compelling ways, which contains an invitation or appeal. Persuasive communication seeks to encourage or make someone do something like what will be done.(Effendy, 1998). Thus, persuasive communication is one way for someone to persuade others to do something according to the wishes of the persuader and happily without feeling forced. Persuasion comes from the Latin term persuasion, whose verb is communicant, which means to persuade, invite or seduce (Effendy, 1998). Teachers in classroom learning activities use persuasive communication to influence students' minds by providing various materials according to student's abilities through interaction between them . Through this persuasive communication interaction, the teacher is fully involved in changing or influencing their students' beliefs, attitudes, and behavior to act following what the teacher expects in learning. This goal can only be achieved when a teacher can convey his message with a psychological approach, and messages like that are called persuasive.

Emotionally persuasion usually touches on the affective aspect, namely matters relating to a person's emotional life. In this way, aspects of one's sympathy and empathy are aroused, so a happy process occurs in the person being persuaded.(Bungin, 2008) The latest model of the persuasion process is rooted in Greenwald's cognitive response model. In Greenwald's model, it is stated that attitude change is mediated by thoughts that occur in the minds of the recipients of the message.(Severin \& James, 2008) It is further stated that the durability of a message and its reception are two different things. A person can study the material in a message without experiencing a change in attitude. In some instances of persuasion, the recipient of the message considers it, relating it to existing attitudes, knowledge, and feelings. In doing so, the message's recipient repeats the stored cognitive material. Cognitive response to a persuasive message is an essential part of the persuasion process that should not be ignored. 
Severin and James revealed the main models of the persuasion process are: (1) McGuire's information processing theory; (2) Petty and Cacioppo's elaboration likelihood model; (3) Chaiken, Liberman, and Eagly's heuristic-systematic models. McGuire's information processing states that attitude change consists of six stages, each critical event that serves as a benchmark for the next stage. These stages are: (a) the persuasive message must be communicated, (b) the recipient will pay attention to the message, (c) the recipient will understand the message, (d) the recipient is influenced and convinced by the arguments presented, (e) the adoption position is reached, and (f) the desired behavior occurs. At the same time, the systematic-heuristic model describes two ways of processing persuasive messages-systematic and heuristic. Systematic processing reflects careful, analytical, and conscientious observation of messages. People should be motivated to practice systematic processing, and this can be influenced by situational variables such as time pressure or lack of expertise in a particular area. Heuristic processing is a more straightforward way of using predictive rules or schemes to form judgments or make decisions.(Severin \& James, 2008)

The elaboration likelihood model suggests two routes to attitude change - the central route and the external route. The central route is used when the receiver is actively processing the information and is persuaded by the rationality of the argument. The external route is used when the recipient does not devote cognitive energy to evaluating arguments and processing information in the message and is more guided by external cues, including the credibility of the source, the style, and format of the message, the mood of the recipient, Etc. If the central route to persuasion is active, then the receiver is involved in high elaboration. If the activity is an external route, the receiver is low elaboration.

The success of persuasive communication is how involved the message's recipient is. Teachers involve themselves with students through messages conveyed, words, invitations, teaching positions. Message recipients (students) will provide teachers who can foster constructive (constructive) situations so that students commit to being willing to be involved in the learning process. Azwar suggests that in the learning process, students expect the form of expectancy values, following the sound of his theory that humans learn about an expectation or expectancy, namely the existence of trust in positive or negative responses.(Azwar, 1995) If the student has confidence, expectancy is always consistently confirmed. Based on this belief, an individual's attitude towards something can be formed. Persuasive communication in education aims to create a sense of trust from the recipient of the message to follow the message conveyed through how to build student attention so that the learning process is expected to take place effectively. Therefore the source can build interest from the targets faced.

\section{Coercive and reward power}

Coercive power is the power to punish all consequences of actions that are unpleasant for those who accept them. To modify behavior, punishing behavior that is not good/detrimental to the organization to turn it into healthy behavior. Coercive power in the context of this study found that non-verbal teacher communication was indicated by coercive non-verbal communication. In this case, as the leader of a lesson, the teacher gives punishment and controls. The student, as the leader, realizes that if he does not obey it, there will be adverse effects that can arise. A wise leader can use this power in education and positive direction to subordinates. Not just because of feeling happy or unhappy or other subjective factors.

Likewise, the reward power that the teacher carries out in learning with a multicultural perspective is carried out by giving rewards.(Gumiandari \& Nafi'a, 2020) Reward power, in this case, is in the form of power to give positive benefits or rewards to those who are led. Of course, this can be done in that the leader has the ability and resources to reward subordinates who follow his directions. Awards can be granting autonomy rights to an area that excels, promotions, money, more challenging work, Etc. 


\section{Personal Imitation}

Education with a multicultural perspective does not only require theories or concepts. So far, there have been quite several theories about multicultural education that have been formulated and explained in various articles, books, and many research results. According to Mundiri that the implementation of multicultural education in schools is more appropriate through a modeling approach, personal imitation (uswah) carried out by teachers. Because multicultural education is also a behavior (behavior), not just knowledge so that students can internalize it, it must be exemplified, not just taught.(Wahid et al., 2020)

Based on the study results, it was found that the model and meaning of teacher communication in multicultural-minded learning was carried out by forming multicultural insight and behavior within the teacher. This behavior is carried out in learning in the classroom and carried out outside the classroom. Thus, in the internalization of multicultural values, a model is needed. A model that students in the surrounding environment can find. Students need real examples, not just examples written in books, let alone imaginary examples. This is in line with Berk's statement quoted by Sit, M (2010) that tolerant, egalitarian behavior and other behaviors in line with the multicultural spirit are obtained in the same way as other responses, namely through modeling and reinforcement.

There will be an internalization of various moral, prosocial, and other behaviors through modeling learning for suitable action. Likewise, according to Social Learning Theory in Bandura cited by Hadiwinarto, human behavior is obtained through model observation, from observing other people, forming new ideas and behaviors, and finally being used as a direction for action. Because someone can learn from examples of what other people do, at least approach the behavior of others, and avoid mistakes made by others (Hadiwinarto, 2010).

\section{Educational Interaction Vertically and Horizontally}

Education is one form of human interaction and social action that is possible through a human relationship through individual roles, which are applied through the learning process. Learning is a process of interaction between educators and students. The teacher as an educator is the essential component in the learning process because the teacher deals directly with students as subjects and objects of learning. The provision of practical learning requires systematic elements such as teachers, students, learning objectives, teaching materials, learning models, learning methods, learning media, and the formed class atmosphere. Usman states that the teaching and learning process is a process that contains a series of actions of teachers and students based on reciprocal relationships that take place in educational situations to achieve specific goals. The reciprocal relationship between teachers and students is the main requirement for the teaching and learning process (Usman, 2008).

Success in teaching and learning activities can be seen from the results, but the process must still be considered. In this process, students will carry out teaching and learning activities. A good and correct process is likely to give good results as well (Sardiman, A, 2007). Learning outcomes will be optimal if good educative interaction in the classroom. Educational interaction must describe a two-way active relationship with knowledge as the medium so that the interaction is a meaningful and creative relationship. Thus, students are expected to be more active in teaching and learning activities and improve student learning outcomes. Educational interaction takes place in a bond to carry out educational and teaching goals or better known as teaching and learning interactions (Sardiman, A, 2007). The educative interaction between teacher and student elements must be active. It is impossible for an educational interaction process to occur if only one element is active.

Based on the study results, it was found that in the context of internalizing Islamic Religious Education with a multicultural perspective, the communication model and the meaning of teacher interactions were educational interactions between themselves and students. Education is an interactive process between educators and students to help students achieve educational goals.(Zaini, 2009) This interaction can occur in the educational 
environment such as family, school, and community. In a family environment, interactions occur between parents as educators and children as students. All parents want their children to be good, pious, intelligent, and successful. However, most of them do not have a written plan, clear and detailed because parents do not know what, how, and when to give to their children, to achieve noble goals.(Naim \& Sauki, 2009).

The interaction in this study is a reciprocal relationship between teachers and students that is the main requirement for the ongoing learning activities or teaching and learning process. Interaction in teaching and learning events has a broader meaning, not just in the relationship between teachers and students but also in educational interactions. The teacher is a position or profession that requires particular skills as a teacher (Usman, 2008).

One of the main things in this social order is the emphasis on communication patterns that rely on egalitarian concepts at the horizontal level and piety at the vertical level. The Prophet has laid the foundations of a civil society that is religious, free, and achieves freedom, especially in religion, economy, social and politics. The civil society built by the Prophet has the characteristics of a community of faith and piety; a democratic and civilized society that respects differences of opinion; a society that respects human rights; society is orderly and aware of the law; a creative, independent and confident society; a society that has a competitive spirit in a cooperative atmosphere, full of brotherhood with other nations with a universal (pluralistic) human spirit. The Prophet's civilized social system has superior characteristics, equality, istiqomah, prioritizes participation, and democratization. These superior characteristics remain relevant in the context of different times and places so that basically, the principle is feasible to apply, especially in Indonesia, which is predominantly Muslim.

Thus, communication and interaction in learning occupy a very urgent position. Learning is a synergistic process between students as objects of teaching (learning) and teachers as sources of subjects who, after going through various ways of reading, formulating materials are used for teaching. The process of interaction both in the classroom and outside the classroom is what is in the future referred to as the teaching and learning process. The teaching and learning process between teachers and students will increasingly have a good weight if there is good communication between the two, in this case, transferring knowledge to students (Purwowidodo \& Yasin, 2021). These activities will be carried out well by implementing discipline in the teaching and learning process with the method of giving theory in the room and practical guidance in the field.

Teachers interact with students through good communication and direct contact with students. Interactions used are more empathetic, sympathetic to students so that they also feel what students want and feel (Amalia, 2020). One of the efforts of teachers in interacting with students is by giving prestige to students in the form of other grades that can do assignments correctly and adequately and get closer to students directly by making direct social contact so that in learning activities, students do not feel reluctant to the teacher in participating in learning activities (Wibowo, 2021). The learning objectives all point to the same essence: the learning objectives are the achievement of changes in student behavior or competence after participating in learning activities.

In communication between teachers and students, of course, meets the requirements in communication theory which requires at least two people to be involved. Interpersonal communication involves at least two people with distinctive characteristics, values, opinions, attitudes, thoughts, and behaviors (Nasukah et al., 2020). In addition, interpersonal communication also demands giving and receiving between the actors involved in the communication. In other words, communicators exchange information, thoughts, and ideas. Interpersonal communication is a unique form of human communication that occurs when we interact simultaneously and mutually influence each other (Mahmud \& Sanusi, 2021). Simultaneous interaction means that communicators have the same action on information simultaneously. Mutual influence means that the communicators are affected by each other 
due to their interaction. Interaction affects their thoughts, feelings, and the way they interpret information.

\section{CONCLUSION}

Verbal communication is a form of teacher communication done in writing or verbally. In the process, the delivery of multicultural messages is carried out in the form of verbal learning. However, it is also done through writing on the school walls, both in Indonesian and in Arabic. The message contained in the article is a message about the value of diversity which demands a mutual understanding of the nature of differences. In the process of oral communication with indoctrination techniques, there are stages to carry out the indoctrination technique procedure, namely a) the brainwashing stage, b) the stage of establishing fanaticism, and c) the stage of inculcating doctrine.

\section{ACKNOWLEDGMENT}

The research team of the model of Teachers' communication based on multicultural values in rural early childhood schools would like to thank all the contributors to this research, both informants and the leadership of Nurul Jadid University, who have funded this research process.

\section{REFERENCES}

Adham, A. S., \& Mahmudah, F. N. (2021). "Art and Culture" Learning Management for Students' Increased Achievement During the Covid-19 Pandemic. Al-Tanzim: Jurnal Manajemen Pendidikan Islam, 5(1), 106-114. https://doi.org/10.33650/altanzim.v5i1.1904

Amalia, V. (2020). Strategi Komunikasi Humas dalam Meningkatkan Public Trust di Perguruan Tinggi (Studi Kasus di Universitas Nurul Jadid, Paiton, Probolinggo). AlTanzim: Jurnal Manajemen Pendidikan Islam, 4(1), 13-23. https://doi.org/10.33650/al-tanzim.v4i1.812

Amaliyah, A., Rahman, F., \& Maryam, S. (2022). Enhancement School Competitiveness Through A Literacy Culture Based on Local Wisdom. Jurnal Obsesi: Jurnal Pendidikan Anak Usia Dini, 6(3), 2325-2333. https:// doi.org/10.31004/obsesi.v6i3.2094

Azwar, S. (1995). Sikap manusia : teori dan pengukurannya. Pustaka Pelajar.

Baharun, H. (2015). Penerapan Pembelajaran Active Learning untuk Meningkatkan Hasil Belajar Siswa di Madrasah. Pedagogik; Jurnal Pendidikan, 2(2).

Bali, M. M. E. I., Muali, C., \& Munawaroh, L. (2020). Self-Efficacy sebagai Media Peningkatan Profesionalisme Guru di Madrasah. Risalah: Jurnal Pendidikan Dan Studi Islam, 6(1), 244-257. https://doi.org/10.31943/jurnal_risalah.v6i2.158

Bungin, B. (2008). Sosiologi Komunikasi; Teori Paradigma dan Diskursus Teknologi Komunikasi di Masyarakat. Prenada Media.

Effendy, O. U. (1998). Hubungan Masyarakat Suatu Studi Komunikasi. Remaja Rosdakarya.

Fachri, M., Wahid, A. H., \& Lailiyah, K. (2020). Joyful Learning Berbasis Hypercontent dalam Meningkatkan Motivasi Belajar Siswa pada Pembelajaran Pendidikan Agama Islam (PAI) di Sekolah. Edureligia: Jurnal Pendidikan Agama Islam, 4(2), 170-184. https:// doi.org/10.24235/tarbawi.v4i1.4209

Farisi, Y. Al, \& Wafi, A. (2021). Peningkatan Kinerja Guru Melalui Penguatan Kecerdasan Spiritual Di Sekolah. Managere: Indonesian Journal of Educational, 3(1), 85-95. https://doi.org/10.52627/ijeam.v3i1.126

Gumiandari, S., \& Nafi'a, I. (2020). The role of Cirebon Women Ulama in Countering Religious Radicalism. QIJIS (Qudus International Journal of Islamic Studies), 8(1), 33. https:// doi.org/10.21043/qijis.v8i1.6430

Hadiwinarto, H. (2010). Penajaman Penilaian Karakter dan Budi Pekert. Bahana Media Wirayuda. 
Iltiqoiyah, L. (2020). Manajemen Pembelajaran melalui Pendekatan BCCT dalam Meningkatkan Multiple intelligences Anak. Jurnal Obsesi : Jurnal Pendidikan Anak Usia Dini, 5(2), 1368-1381. https:// doi.org/10.31004/obsesi.v5i2.781

Intania, I. (2020). Interaksi Simbolik Dan Imaji Religious Dalam Membangun Citra Pondok Pesantren Nurul Jadid. Atthulab: Islamic Religion Teaching and Learning Journal, 5(1), 71-85. https:// doi.org/10.15575/ath.v5i1.7317

Jiang, Y., Lee, C.-K. J., Wan, Z. H., \& Chen, J. (2021). Stricter Teacher, More Motivated Students? Comparing the Associations Between Teacher Behaviors and Motivational Beliefs of Western and East Asian Learners. Frontiers in Psychology, 11, 564327. https://doi.org/10.3389/fpsyg.2020.564327

Kinoshita, K. (2007). Critical Inquiry, Instructional Leadership and Closing the Achievement Gap: Principal Learning in a University-School District Professional Development Program. University of Washington.

Mahmud, H., \& Sanusi, S. (2021). Training , Managerial Skills , And Principal Performance At Senior High Shool in North Luwu Regency. Al-Tanzim: Jurnal Manajemen Pendidikan Islam, 5(2), 27-39. https://doi.org/10.33650/al-tanzim.v5i2.2150

Mubarak, A. (1999). Psikologi Dakwah. Firdaus.

Muhaimin, M. (2005). Pengembangan Kurikulum Pendidikan Agama Islam. Rajagrafindo Persada.

Mulkhan, A. M. (2005). Kesalehan Sosial. PSAP.

Mundiri, A., \& Adhimiy, S. (2019). Religious Authoritative Parenting Berbasis Quantum Meaningfullness of Life; Melejitkan Potensi Raih Prestasi. Pustakan Nurja.

Mundiri, A., \& Hamimah, S. (2022). Early Childhood Behavior Management Strategy based on Fun Learning Environment. Jurnal Obsesi: Jurnal Pendidikan Anak Usia Dini, 6(4), 2583-2595. https://doi.org/10.31004/obsesi.v6i4.2063

Mundiri, A., \& Tohet, M. (2018). Contestation of Religious Identity in the Cyber World: A Case Study of arrahmah.com and VOA Islam Dealing with Religious Others on Facebook. Walisongo: Jurnal Penelitian Sosial Keagamaan, 26(2), 391-416. https://doi.org/10.21580/ws.26.2.3244

Naim, N., \& Sauki, A. (2009). Pendidikan Multikultural; Konsep dan Aplikasi. Arruzz Media.

Nasukah, B., Sulistyorini, S., \& Winarti, E. (2020). Peran Komunikasi Efektif Pemimpin Dalam Meningkatkan Kinerja Institusi. AL-TANZIM: Jurnal Manajemen Pendidikan Islam, 4(1), 81-93. https://doi.org/10.33650/al-tanzim.v4i1.899

Page, A., \& Jones, M. (2018). Rethinking Teacher Education for Classroom Behaviour Management: Investigation of an Alternative Model using an Online Professional Experience in an Australian University. Australian Journal of Teacher Education, 43(11), 84-104. https:// doi.org/10.14221/ajte.2018v43n11.5

Purwowidodo, A., \& Yasin, M. (2021). Development of Corporate Marketing Communication (CMC) Branding Model in Iain Tulungagung: Toward the Era of World Class University. AL-TANZIM: Jurnal Manajemen Pendidikan Islam, 5(1), 115-128. https://doi.org/10.33650/al-tanzim.v5i1.1882

Ratcliff, N. J., Jones, C. R., Costner, R. H., Savage-Davis, E., Sheehan, H., \& Hunt, G. H. (2010). Teacher Classroom Management Behaviors and Student Time-on-Task: Implications for Teacher Education. Action in Teacher Education, 32(4), 38-51. https:// doi.org/10.1080/01626620.2010.549714

Rizqiyah, L. (2020). Melejitkan Ghiroh Belajar Santri Melalui Budaya Literasi di Pesantren. TADRIS: Jurnal Pendidikan Islam, 15(1), 108-117. https://doi.org/10.19105/tipi.v15i1.3048

Rozi, F., \& Maulidiya, H. (2022). The Sekolah Sak Ngajine Program; The Habit of loving the Qur' an from an Early Age based on Tilawati. Jurnal Obsesi: Jurnal Pendidikan Anak Usia Dini, 6(3), 1667-1676. https:// doi.org/10.31004/obsesi.v6i3.1636

Sardiman, A, M. (2007). Interaksi dan Motivasi Belajar Mengajar. Rajawali Pers. 
Saud, U. S. (2009). Pengembangan Profesi Guru. Alfabeta.

Severin, W. J., \& James, W. T. (2008). Teori Komunikasi; Sejarah, Metode,\& Terapan di Dalam Media Massa. Kencana.

Sholeha, W., \& Anggraini, Y. (2022). Intercultural Communication : Strategy to Improve School Competitiveness Based on Public Demand. Jurnal Obsesi: Jurnal Pendidikan Anak Usia Dini, 6(4), 438-447. https:/ / doi.org/10.31004/obsesi.v6i4.2123

Slamet, S. (2009). Efektivitas Komunikasi dalam Dakwah Persuasif. Jurnal Dakwah, 10(2), 179193.

Soekanto, S. (1990). Sosiologi Suatu Pengantar. Rajagrafindo Persada.

Sudjana, N. (1988). Dasar-Dasar Proses Belajar Mengajar. Sinar Baru Algensindo.

Susanto, A. (1992). Komunikasi Dalam Teori dan Praktek. Mandar Maju.

Umiarso, \& Hidayati, N. (2022). Improving Children's Cognitive Intelligence Through Literacy Management. Jurnal Obsesi: Jurnal Pendidikan Anak Usia Dini, 6(3), 1588-1598. https://doi.org/10.31004/obsesi.v6i3.1817

Usman, M. U. (2008). Menjadi Guru Profesional. Remaja Rosdakarya.

Wahid, A. H., Najiburrahman, N., \& Muali, C. (2020). Anti-Radicalism Education; Amplification of Islamic Thought and Revitalization of the Higher Education in Indonesia. Proceedings of the International Conference on Industrial Engineering and Operations Management, 3802-3814.

Wahid, A. H., Qodriyah, K., \& Wahyuni, S. (2022). Building a Literacy Culture Based on Local Wisdom through Women's Leadership. Jurnal Obsesi: Jurnal Pendidikan Anak Usia Dini, 6(4), 2533-2543. https://doi.org/10.31004/obsesi.v6i4.2044

Wibowo, A. (2021). Kepemimpinan Perempuan dalam Menciptakan Sekolah Ramah Anak. Quality, 9(1), 87-102. https://doi.org/10.21043/quality.v9i1.10109

Windayanti, K., Suarnajaya, I. W., \& Agustini, D. A. E. (2017). An Analysis of Communication Strategies Used by Teacher In English Teaching and Learning at SMA Saraswati Singaraja. Jurnal Pendidikan Bahasa Inggris, 5(2), 1-11.

Zaini, M. (2009). Pengembangan Kurikulum Konsep Implementasi Evaluasi dan Inovasi. Teras.

Zamroni, Amir, \& Saleha, L. (2021). Pengelolaan APE Berbahan Limbah untuk Meningkatkan Kecerdasan Kognitif Anak. Jurnal Obsesi: Jurnal Pendidikan Anak Usia Dini, 5(2), 1382-1395. https://doi.org/10.31004/obsesi.v5i2.763

Zamroni, Z., Bali, M. E. I., Holidi, M., Ervansyah, F., Abbas, A. R., Abdullah, D., \& Erliana, C. I. (2021). Indigeneity and the Plight of Managing Behaviour; A Collaborative Instructional Model Based on Digital Classroom. Turkish Online Journal of Qualitative Inquiry (TOJQI), 12(4), 1655-1660. 